Archived version from NCDOCKS Institutional Repository http://libres.uncg.edu/ir/asu/

\title{
Appalachỉan
}

B O O N E, NORT H C A R O L I A

\section{Magnetic Susceptibility As A Proxy For Coal Ash Pollution Within Riverbed Sediments In A Watershed With Complex Geology (Southeastern USA)}

\author{
By: Ellen A. Cowan, Erin E. Epperson, Keith C. Seramur, \\ Stefanie A. Brachfeld, and Steven J. Hageman
}

\begin{abstract}
A study of near surface sediments from the Dan River (southeastern USA) was conducted to assess the use of magnetic properties as proxies of coal ash after a recent spill. The watershed geology is diverse and potentially contributes magnetic minerals to riverbed sediment from diabase dikes in the Dan River Triassic Basin and from granitic gneiss outside the basin. Coal ash is heterogeneous, including aluminosilicate spheres, amorphous particles and carbonaceous rods and lacy particles. The magnetic fraction of ash from the failed storage pond is up to 17 $\mathrm{wt} \%$ and is mostly composed of black spheres with maghemite and magnetite. Ash was detected in riverbed sediment from quiet water settings such as inside of meander bends, the confluence of tributary streams and near islands between the spill site and 20 miles downstream in the Schoolfield Reservoir, Danville, VA. The strong magnetic signal is detected above background in riverbed samples and is strongly positively correlated with total ash; elevated low field magnetic susceptibility ( $X L F)$ is evident in samples with $\geq 12 \%$ ash content. Anhysteretic remanent magnetization and hysteresis parameters delineate native sediment, ash-bearing sediment, and diabase dikes. Between 20 and 70 miles downstream of the spill site, ash concentrations were either buried or too low due to dilution with native sediment to be detected with $\chi$ LF in riverbed samples.
\end{abstract}

Cowan, E.A., Epperson, E.E., Seramur, K.C. et al. Magnetic susceptibility as a proxy for coal ash pollution within riverbed sediments in a watershed with complex geology (southeastern USA). Environ Earth Sci 76, 657 (2017). https://doi.org/10.1007/s1 2665-017-6996-8. Publisher version of record available at: https:// link.springer.com/article/10.1007/s1 2665-017-6996-8 


\title{
Magnetic susceptibility as a proxy for coal ash pollution within riverbed sediments in a watershed with complex geology (southeastern USA)
}

\author{
Ellen A. Cowan ${ }^{1}$ (D) Erin E. Epperson ${ }^{1,3} \cdot$ Keith C. Seramur $^{1} \cdot$ Stefanie A. Brachfeld $^{2} \cdot$ \\ Steven J. Hageman ${ }^{1}$
}

Received: 25 July 2017/Accepted: 25 September 2017/Published online: 9 October 2017

(C) Springer-Verlag GmbH Germany 2017

\begin{abstract}
A study of near surface sediments from the Dan River (southeastern USA) was conducted to assess the use of magnetic properties as proxies of coal ash after a recent spill. The watershed geology is diverse and potentially contributes magnetic minerals to riverbed sediment from diabase dikes in the Dan River Triassic Basin and from granitic gneiss outside the basin. Coal ash is heterogeneous, including aluminosilicate spheres, amorphous particles and carbonaceous rods and lacy particles. The magnetic fraction of ash from the failed storage pond is up to $17 \mathrm{wt} \%$ and is mostly composed of black spheres with maghemite and magnetite. Ash was detected in riverbed sediment from quiet water settings such as inside of meander bends, the confluence of tributary streams and near islands between the spill site and 20 miles downstream in the Schoolfield Reservoir, Danville, VA. The strong magnetic signal is detected above background in riverbed samples and is strongly positively correlated with total ash; elevated low field magnetic susceptibility $\left(\chi_{\mathrm{LF}}\right)$ is evident in samples with $\geq 12 \%$ ash content. Anhysteretic remanent magnetization and hysteresis parameters delineate native
\end{abstract}

Electronic supplementary material The online version of this article (doi:10.1007/s12665-017-6996-8) contains supplementary material, which is available to authorized users.

Ellen A. Cowan

cowanea@appstate.edu

1 Department of Geological and Environmental Sciences, Appalachian State University, Box 32067, Boone, NC 28608, USA

2 Department of Earth and Environmental Studies, Montclair State University, Montclair, NJ 07043, USA

3 Present Address: Department of Geosciences, Georgia State University, Atlanta, GA 30302, USA sediment, ash-bearing sediment, and diabase dikes. Between 20 and 70 miles downstream of the spill site, ash concentrations were either buried or too low due to dilution with native sediment to be detected with $\chi_{\mathrm{LF}}$ in riverbed samples.

Keywords Environmental magnetism - Duke Energy spill · Dan River · Coal combustion residue · Magnetic susceptibility · ARM

\section{Introduction}

On February 2, 2014 a large drain (48" diameter) underlying the coal combustion residue (CCR) surface impoundment at the decommissioned Duke Energy Dan River Steam Plant collapsed, initiating a coal ash spill lasting several days and attracting the attention of the public and environmental professionals from the Federal government and two southeastern states (USFWS 2014; VDEQ 2014). An estimated 39,000 tons of coal ash mixed with 27 million gallons of water from the CCR impoundment were released directly into the Dan River at Eden, North Carolina incurring an estimated monetized cost of nearly $\$ 300$ million within the first 6 months of the spill (Lemly 2015). By February 5, 2014 the ash plume reached the Kerr Reservoir in Staunton River State Park in Virginia, some 70 miles downstream (Fig. 1a; VDEQ 2014). In the Dan River, turbidity from the spill cleared rapidly resulting in deposition on the riverbed, banks and in sand bars mostly between the Steam Plant and 20 river miles downstream in the Schoolfield Reservoir in the city of Danville, VA (USEPA 2014). The thickness of ash on the riverbed ranged from 6 feet (1.8 meters) deposited near the storm drain to a few inches downstream near Danville 


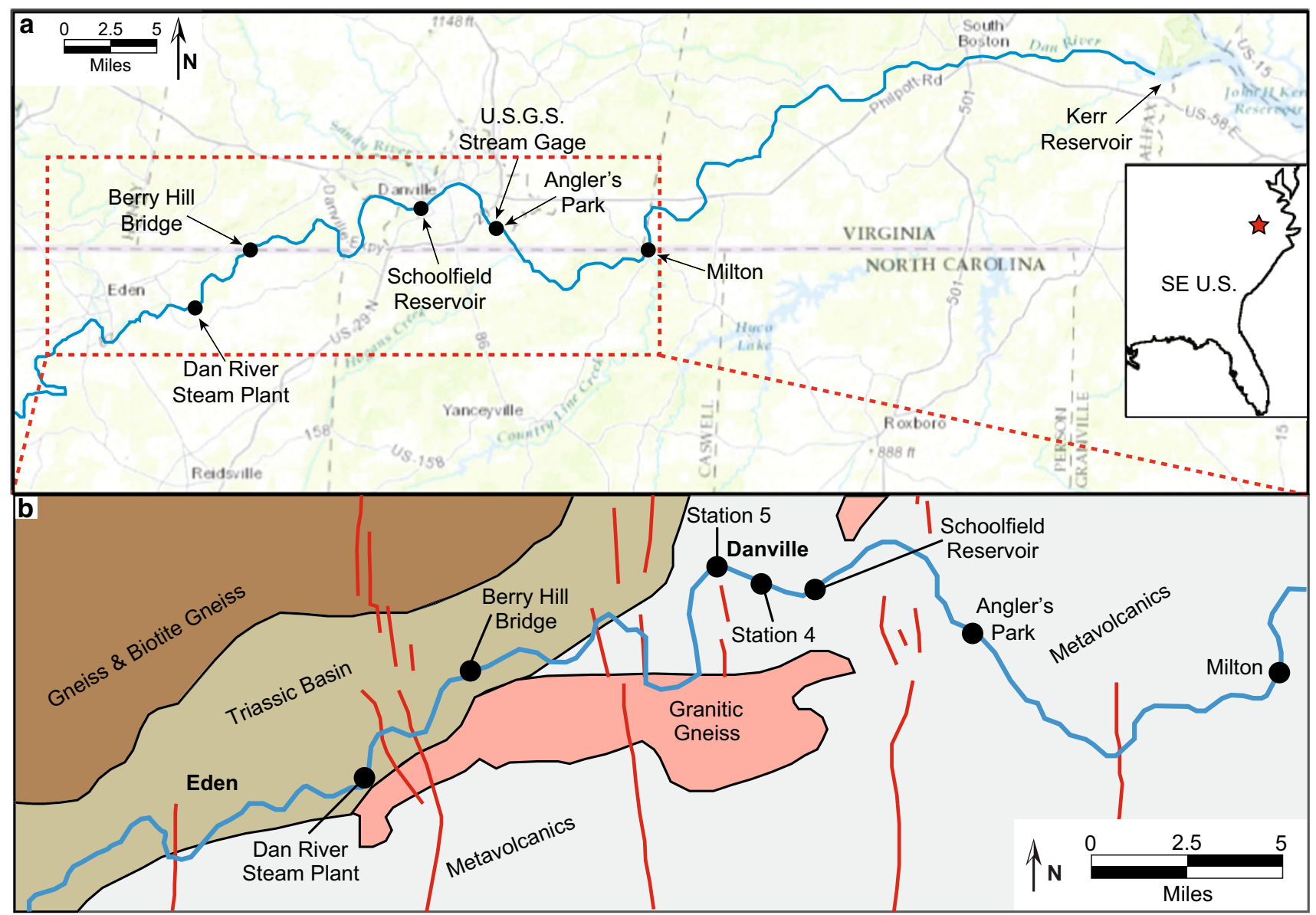

Fig. 1 a Location map of sampling access points along the Dan River in North Carolina and Virginia. The coal ash spill originated from the Dan River Steam Plant. Location of U.S.G.S. Stream gage used for Supplemental Fig. S3 is shown. b Generalized geology map of the

(USEPA 2014). A vacuum truck was used near the site of the spill to remove the thickest and most visible ash deposits in late February in spite of challenges introduced by high river discharge from snowmelt and rainfall (VDEQ 2014). Ash and sediment deposits within the Schoolfield Reservoir, the drinking water supply for Danville were dredged in May-June 2014 (USEPA 2014). It is estimated, however, that less than $10 \%$ of the total ash was removed (Schlanger 2014). Thus, most of the ash is presumed to be buried within the bed of the Dan River or has reached its final depositional site in the Kerr Reservoir.

This study focuses on detecting coal ash deposited in the bed and banks of the Dan River based on sampling conducted 8 and 15 months after Duke Energy's spill. The effectiveness of using magnetic susceptibility to quantify ash mixed with Dan River sediment is tested. Previously, we used magnetic susceptibility as an analytical tool to quantify ash from the Tennessee Valley Authority (TVA) spill at the Kingston Fossil Plant (Cowan et al. 2013, 2015). In 2008, coal ash slurry spilled directly from an ash storage area shown in map a. Diabase dikes are shown by red lines. Stations 4 and 5 where cores discussed in the paper were collected are also shown. Geology is complied from Rhodes and Conrad (1985) and Rader and Evans (1993)

cell into the Emory River and after these deposits were scoured, suspended and mixed with river sediment the concentration of ash could not be visually quantified. The widely used method to quantify ash in riverbed sediment is by point counting aliquots under polarized light microscopy (PLM), which is slow and laborious. In the Watts Bar Reservoir System impacted by the TVA spill we used the mass-normalized low field magnetic susceptibility $\left(\chi_{\mathrm{LF}}\right)$ of riverbed samples to measure the coal ash content. This rapid, efficient and inexpensive method predicted ash concentrations greater than 15\% (Cowan et al. 2013, 2015).

Due to the association of CCRs with heavy metals, primarily As and Se, residual ash can pose a substantial threat to drinking water, recreation, aquatic organisms and habitat (Lemly 2015; Lemly and Skorupa 2012; Otter et al. 2012). In the case of the extensively studied TVA spill, ecological risks (moderate to low) were detected for benthic organisms immersed in sediments that contained greater than $40 \%$ residual ash content (Carriker et al. 2015). Therefore, it is important to identify areas within the 
Dan River where ash has collected within the riverbed. The Duke Energy spill also has several important differences from the TVA spill, including ash composition, stream hydrology and watershed geology.

The effectiveness of $\chi_{\mathrm{LF}}$ as a proxy for coal ash mixed with river sediments depends on the contrast between magnetic characteristics of the coal ash and native river sediments. This partly depends on characteristics that affect the ferromagnetic particulates in CCRs from a coal burning plant, which have been shown to be variable (Jordanova et al. 2006; Blaha et al. 2008). Although, unburned coal is either paramagnetic or diamagnetic (Alexander et al., 1979), the products of combustion can be enriched in magnetite $\left(\mathrm{Fe}_{3} \mathrm{O}_{4}\right)$ by as much as 160,000 ppm (Flanders 1994). Oxidation of pyrite $\left(\mathrm{FeS}_{2}\right)$ in pulverized coal at high temperature produces molten iron spheres and sulfur, and the iron oxidizes to form magnetite and hematite (Flanders 1994). Ash from the failed TVA storage cell had a relatively low weight percent magnetic fraction (MF) of $1.4 \%$, which was composed of predominately magnetite and maghemite (Cowan et al. 2013, 2015). However, even a small amount of ferrimagnetic material was sufficient to impart a strong contrast in $\chi_{\mathrm{LF}}$ compared with the paramagnetic or diamagnetic sediments derived from sedimentary rocks in the Emory and Clinch River watershed (Cowan et al. 2013). These sedimentary rocks are not sources of magnetite, a principal mineral carrier of $\chi_{\text {LF }}$. Rather they likely contribute hematite and paramagnetic minerals to the sediment load. Since $\chi_{\mathrm{LF}}$ of hematite is two to three orders of magnitude smaller than magnetite, the effect of hematite in the presence of the magnetite and maghemite in coal ash is negligible (Presuel-Moreno and Sagüés 2009).

There are significant differences between the two coal ash spills; the TVA spill was 140 times larger (VDEQ 2014) and $400,000 \mathrm{~m}^{3}$ of ash remains in the river system after dredging (Walls et al. 2015). Today, monitored natural recovery with verification by long-term sampling is in place as the remediation strategy (Carriker et al. 2015; TVA 2013). Coal ash from the TVA spill entered the Watts Bar Reservoir system, which effectively responds as a lake to fluctuating discharge. In contrast, the Dan River in the vicinity of Eden is a free flowing piedmont stream (Reusser et al. 2015), although there are some small impoundments. Under these conditions, high flow velocities would scour ash from the main channel of the river, redistributing it to areas with slower moving water. This would result in a discontinuous distribution of ash along the affected reach of the river unlike the continuous distribution observed after the TVA spill (Scott and Zeller 2011).

The principal objectives of this study are to (1) determine characteristics of the magnetic fraction of coal ash produced at the Dan River Steam Plant; (2) investigate the ability of $\chi_{\mathrm{LF}}$ to detect coal ash in the riverbed of the Dan River and (3) identify locations within the Dan River where ash was buried in the riverbed up to 15 months after the spill.

\section{Bedrock geology and magnetic mineralogy of the Dan River watershed}

The spill originated within the Dan River Triassic Basin (Fig. 1b). The rocks are primarily sandstone, siltstone, and shale (Kent and Olsen 1997; Reid and Milici 2008; Olsen et al. 2015). Further to the east, the river cuts through felsic metavolcanics and granitic gneiss (Fig. 1b). Jurassic age diabase dikes cut across the river channel throughout the study area (Fig. 1b) and form rounded boulders as they weather at the surface. A previous paleomagnetic study in the Dan River-Danville Basin collected samples 2 miles upstream and 5 miles downstream of the Dan River Steam Plant (Kent and Olsen 1997). This study documented the presence of magnetite, hematite, and iron sulfides in the Triassic sedimentary units (Kent and Olsen 1997). Paleomagnetic studies of Jurassic diabase dikes in the contemporaneous Dan River, Culpepper, Newark, and Hartford Basins show the presence of both low-Ti titanomagnetite and ilmentite (DeBoer and Snider 1979; Smith 1987; Kodama and Mowery 1994).

Dan River sediment is a mixture of the weakly magnetic Triassic sedimentary rocks and the more strongly magnetic Jurassic dikes. Therefore, ash-free river sediment samples were collected upstream of the Dan River Steam Plant to assess the mineralogic and magnetic properties of native sediment. Five mineral types, including iron-bearing minerals as well as quartz and clay were point counted to assess the variability in riverbed sediment (Table 1).

\section{Methods}

\section{Field sampling}

Samples were collected with a trowel and Ekman box corer from the riverbank and center channel using canoes on October 5, 2014 between Leaksville Access (upstream of the Steam Plant) and Draper Landing (downstream). One riverbed sample was collected upstream of the Steam Plant and six samples were collected downstream (all labeled E in Table 1). From May 11-15, 2015 the Dan River was accessed at five locations including Berry Hill Bridge (BH), Schoolfield Reservoir (SR), Angler's Park (AP), Milton River Access (MR) and Kerr Reservoir (KR) in Staunton River State Park (Fig. 1a). At BH samples were collected from the bridge and in other reaches of the river 


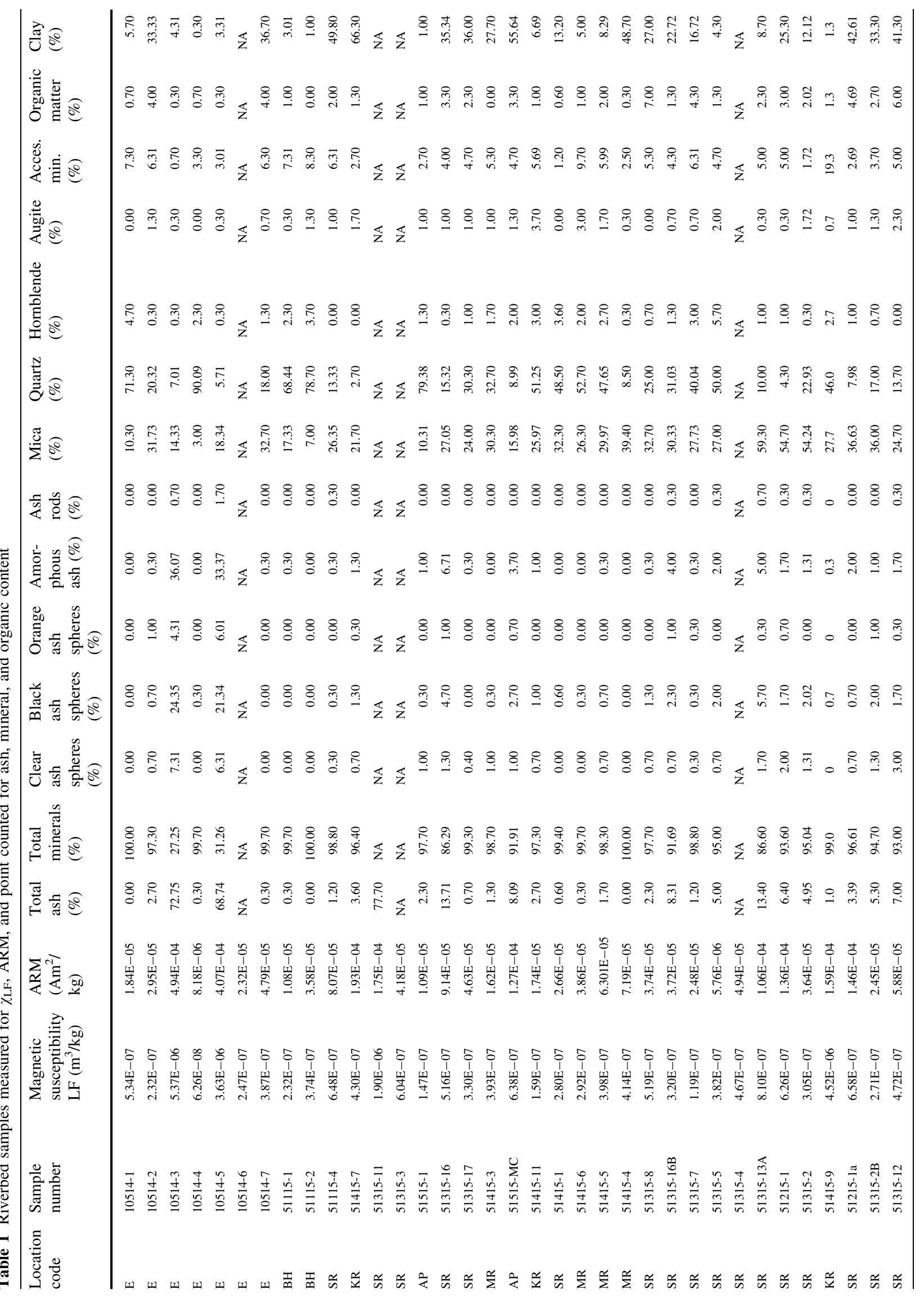




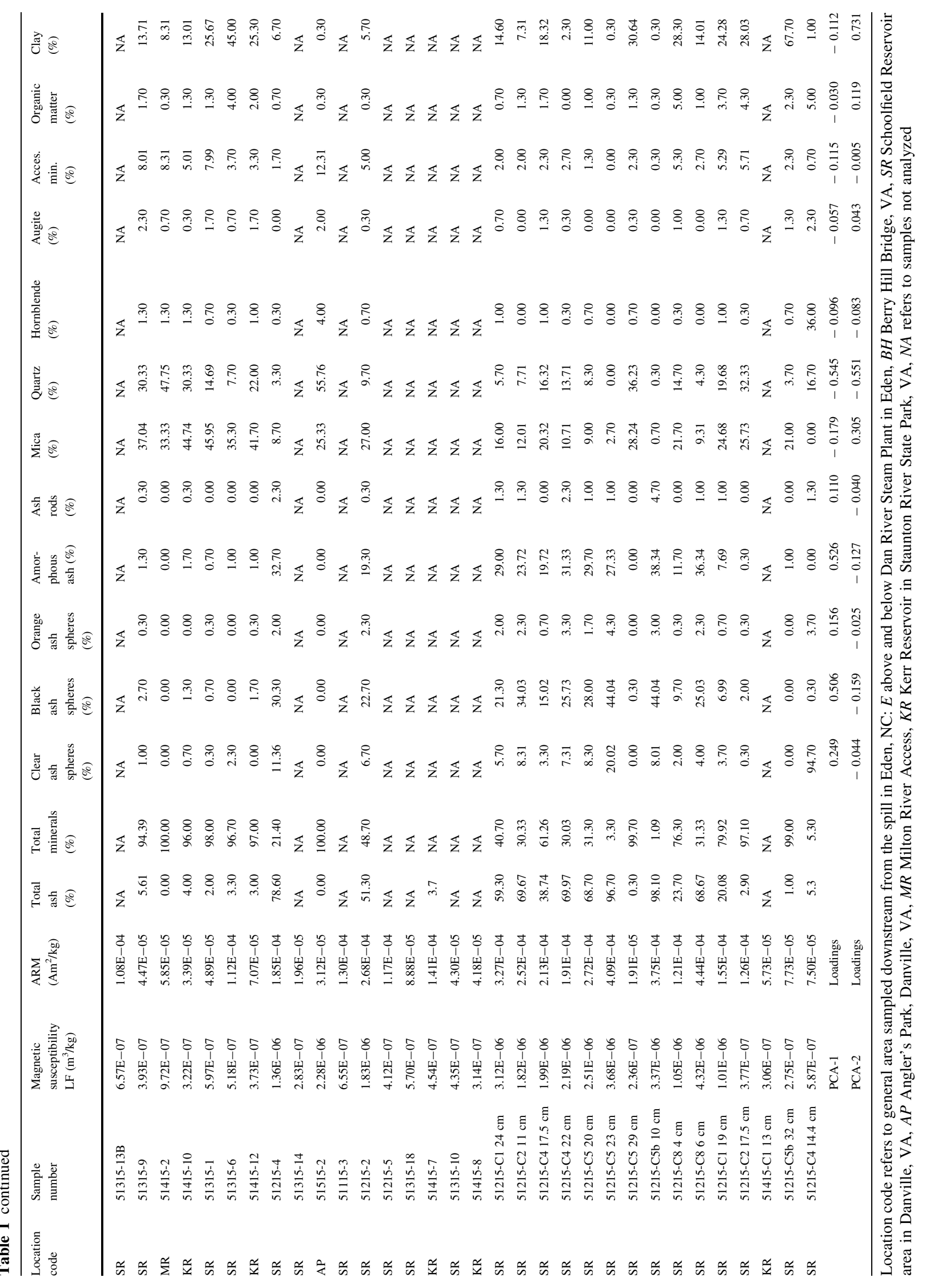


and within KR canoes and a jon boat were used. Forty samples were collected with an Ekman box corer with a 6 in $(15.2 \mathrm{~cm})$ opening. The box corer preserved the sediment water interface while collecting a near surface sample. Twenty push cores collected a $66 \mathrm{~cm}$ long sample within a $2.54 \mathrm{~cm}$ diameter plastic liner. The liners were split along their lengths, photographed, described, and then subsampled. Samples from the CCR pond and the drainpipe were provided by Dr. Madeline Schreiber of Virginia Tech University so the magnetic characteristics of the Dan River Steam Plant CCRs could be investigated (Table 2).

\section{Magnetic measurements}

\section{Magnetic separation}

Magnetic separation of two replicate samples split from a sample from the CCR pond was accomplished by mixing a sediment/water slurry in an approximate ratio of 1:3. The slurry was poured into a series of four $300 \mathrm{ml}$ beakers with 6 magnets attached to their base. After mixing, the slurry settled for $10 \mathrm{~s}$ before being decanted into the next beaker. Particles that remained stuck to the bottom of the beaker were rinsed until only the magnetic particles remained. The process was repeated for four beakers and all the magnetic material was combined into a magnetic fraction (MF) sample. The weight percent MF was then calculated compared to the dry weight of the total sample.

\section{Rock magnetic parameters}

Magnetic measurements were made at the Department of Earth and Environmental Studies at Montclair State University. Air-dried bulk sediment was packed into size 4 gelatin capsules and the mass was recorded. Mass-normalized low field magnetic susceptibility $\left(\chi_{\mathrm{LF}}\right)$ was measured on an AGICO KLY-4 Kappabridge. Anhysteretic remanent magnetization (ARM) was imparted in a peak alternating field of $100 \mathrm{mT}$ and a steady DC field of field of $0.05 \mathrm{mT}$ and measured on an AGICO JR-6 spinner magnetometer.

Magnetic hysteresis parameters including saturation magnetization, saturation remanence, coercivity, coercivity of remanence, and high-field magnetic susceptibility $\left(M_{\mathrm{S}}\right.$, $M_{\mathrm{R}}, H_{\mathrm{C}}, H_{\mathrm{CR}}$, and $\chi_{\mathrm{HF}}$ respectively) were measured on a Princeton Measurement Corp. 390004 Vibrating Sample Magnetometer (VSM) using peak field of 1T. Curie temperature analyses were conducted on bulk sediment samples using the AGICO KLY-4 Kappabridge with a CS-3 furnace attachment. All samples were measured in a flowing argon atmosphere during heating and cooling between room temperature and $700{ }^{\circ} \mathrm{C}$.

\section{PLM, SEM and XRD}

Smear slides were made by spreading a small amount of sample across the surface of a microscope slide with a toothpick. The slide was fixed using Loctite 349 Improv UV Light curing adhesive. Three hundred points were counted at $200 \times$ magnification using a Zeiss Point Counter mounted on a petrographic light microscope (PLM). Each particle was assigned to one of twelve categories including ash spheres (black, clear, orange), amorphous ash, ash rods, minerals including mica, quartz, hornblende, augite, accessory minerals, clay and organic matter (such as aquatic microfossils and plant material). Unidentified particles were skipped and not included in the total count. Rare lacy ash was undifferentiated from amorphous ash.

Particle morphology was imaged on a Quanta FEI 200 Scanning Electron Microscope (SEM) in high vacuum mode at $20 \mathrm{kV}$. Samples were mounted on aluminum stubs and coated with gold. Backscattered electron imaging (BSE) and Energy Dispersive Spectrometry (EDS) were used to identify morphology and for qualitative composition of particles. Powdered samples of the MF and nonmagnetic fraction (NMF) from the CCR pond were analyzed using a Shimadzu XRD-6000 diffractometer with $\mathrm{Cu} \mathrm{K} \alpha$ radiation (tube voltage $40 \mathrm{kV}$ and $30 \mathrm{~mA}$ tube current) by scanning from 2 to $80^{\circ}(2 \theta)$ at a speed of $2^{\circ} / \mathrm{min}$.

\section{Numerical analysis}

Scatter plots of compositional data and $\chi_{\mathrm{LF}}$ employ samples in Table 1 (Total ash $>0.0 \%$ ). For principal components and pairwise correlations, relative abundance data (percentages) were transformed to their arcsine prior to analysis. Samples are considered as three major populations: those collected from the river (Table $1, n=52$ ); those collected from the CCR pond (Table 2; $n=3$ ); those collected from the pond drain pipe (Table $2 ; n=2$ ). Total ash reported for each sample (Tables 1 and 2) is the sum of each ash component relative to the total composition of the sample, not just the ash.

\section{Results}

\section{Magnetic fraction (MF) in CCR pond samples}

The CCR storage pond replicates had 16.0 and $17.1 \mathrm{wt} \%$ MF for samples containing 83 and $93 \%$ total ash, respectively (Table 2). The MF samples are predominantly black spheres (Fig. 2a) with a XRD pattern dominated by maghemite and magnetite (Fig. 2b). Hematite and quartz were also present in the MF sample. The NMF is 
Table $2 \chi_{\mathrm{LF}}, \mathrm{ARM}, \mathrm{MF}$ and point counts of 3 ash samples from the Dan River Steam Plant CCR Pond. DR ASH-1a and 1b are replicate samples of a sample collected from the drainpipe while the spill was in progress

\begin{tabular}{|c|c|c|c|c|c|c|c|c|c|c|c|}
\hline \multirow{2}{*}{$\begin{array}{l}\text { Sample } \\
\text { ID }\end{array}$} & \multirow[t]{2}{*}{ Description } & \multirow{2}{*}{$\begin{array}{l}\chi_{\mathrm{LF}} \mathrm{m}^{3} / \\
\mathrm{kg}\end{array}$} & \multirow{2}{*}{$\begin{array}{l}\mathrm{ARM} \\
\mathrm{Am}^{2} / \mathrm{kg}\end{array}$} & \multirow{2}{*}{$\begin{array}{l}\text { Magnetic } \\
\text { fraction } \\
(\%)\end{array}$} & \multirow{2}{*}{$\begin{array}{l}\text { Total } \\
\text { ash } \\
(\%)\end{array}$} & \multirow{2}{*}{$\begin{array}{l}\text { Total } \\
\text { minerals } \\
(\%)\end{array}$} & \multicolumn{5}{|c|}{ Ash composition } \\
\hline & & & & & & & $\begin{array}{l}\text { Clear ash } \\
\text { spheres } \\
(\%)\end{array}$ & $\begin{array}{l}\text { Black ash } \\
\text { spheres } \\
(\%)\end{array}$ & $\begin{array}{l}\text { Orange ash } \\
\text { spheres }(\%)\end{array}$ & $\begin{array}{l}\text { Amorphous } \\
\text { ash }(\%)\end{array}$ & $\begin{array}{l}\text { Ash } \\
\text { rods } \\
(\%)\end{array}$ \\
\hline $\begin{array}{l}\text { DR ASH- } \\
\text { 1a }\end{array}$ & $\begin{array}{l}\text { Discharge } \\
\text { pipe during } \\
\text { spill }\end{array}$ & $4.16 \mathrm{E}-06$ & $7.25 \mathrm{E}-04$ & - & 85.7 & 14.3 & 14.0 & 35.3 & 2.0 & 34.0 & 0.3 \\
\hline $\begin{array}{l}\text { DR ASH- } \\
1 \mathrm{~b}\end{array}$ & $\begin{array}{l}\text { Discharge } \\
\text { pipe during } \\
\text { spill }\end{array}$ & $4.83 \mathrm{E}-06$ & $8.88 \mathrm{E}-04$ & - & 83.0 & 17.0 & 7.0 & 35.7 & 3.3 & 37.0 & 0 \\
\hline $\begin{array}{l}\text { DR ASH- } \\
2\end{array}$ & Storage pond & $4.61 \mathrm{E}-06$ & $6.86 \mathrm{E}-04$ & - & 93.7 & 6.3 & 15.3 & 24.7 & 4.0 & 48.7 & 1.0 \\
\hline Pond 1 & Storage pond & $5.44 \mathrm{E}-05$ & $1.60 \mathrm{E}-03$ & 17.1 & 83.0 & 17.0 & - & - & - & - & - \\
\hline Pond2 & Storage pond & $5.35 \mathrm{E}-05$ & $1.80 \mathrm{E}-03$ & 16.0 & 93.0 & 7.0 & - & - & - & - & - \\
\hline
\end{tabular}

Pond 1 and Pond 2 are replicate samples of a sample collected from within the pond

comprised of a more diverse group of finer particles than the MF, including clear spheres and semi-translucent irregular amorphous particles (Fig. 2c). The XRD pattern is dominated by quartz and mullite indicating that the bulk of the NMF can be described as aluminosilicate spheres and amorphous particles (Fig. 2d).

\section{Ash morphology}

Black spheres and amorphous ash make up at least $70 \%$ of the ash particles in samples from the storage pond (Table 2). These morphologies have previously been described in the literature (Fisher et al. 1976, 1978; Hower 2012; Wang 2014). Black spheres are opaque under PLM (Fig. 2a). SEMEDS analysis indicates that these spheres consist of aluminosilicates (dark shade in backscatter) that are encrusted with maghemite and magnetite crystals (light shade in backscatter images) forming delicate repeating patterns (Fig. 3). These spheres are referred to as magnetospheres (Magiera et al. 2011) because they carry the magnetic signal and comprise most of the MF in the CCR pond samples. Amorphous ash is opaque and non-opaque, subrounded, angular or infrequently lacy. Lacy amorphous particles are described as carbonaceous by Fisher et al. (1978). We identified similar particles composed mostly of carbon (Supplemental Fig. S1a, b). We also identified a new particle occurring in low abundance that appears rod-shaped (Supplemental Fig. S2c, d). EDS spectra indicates that these particles are also composed of carbon.

\section{Rock-magnetic characterization}

\section{Local bedrock and native sediment}

$\chi_{\mathrm{LF}}$ values for Dan River-Danville Triassic sedimentary units range from $6.95 \times 10^{-8}$ to $1.06 \times 10^{-7} \mathrm{~m}^{3} / \mathrm{kg}$ with an average value of $8.7 \times 10^{-8} \mathrm{~m}^{3} / \mathrm{kg}$ (Supplemental Table S1). Published volume-normalized susceptibility $(k)$ values for Jurassic diabase dikes in the eastern U.S. were converted to mass-normalized units using a density of $2900 \mathrm{~kg} / \mathrm{m}^{3}$. The converted $\chi_{\mathrm{LF}}$ values range from 6.20 to $8.60 \times 10^{-6} \mathrm{~m}^{3} / \mathrm{kg}$ with an average value of $7.03 \times 10^{-6}$ $\mathrm{m}^{3} / \mathrm{kg}$ (DeBoer and Snider 1979).

Ash-free samples collected upstream of the Steam Plant represent a mixture of sediment derived from both the Triassic sedimentary rocks and diabase dikes (Fig. 1b). The susceptibility of ash-free sediment ranges from $6.26 \times 10^{-8}$ to $5.34 \times 10^{-7} \mathrm{~m}^{3} / \mathrm{kg}$ with an average value of $3.14 \times 10^{-7} \mathrm{~m}^{3} / \mathrm{kg}$. This suggests the native sediment contains $0-5$ wt $\%$ of material derived from the diabase dikes, although some of the higher-amplitude values may also be skewed by quartz grains observed to have black iron-oxide coatings.

\section{Storage pond and river sediment samples}

$\chi_{\mathrm{LF}}$ of samples from the river, drainage pipe, and storage pond range over three orders of magnitude from $6.3 \times 10^{-8}$ to $5.44 \times 10^{-5} \mathrm{~m}^{3} / \mathrm{kg}$ (Fig. 4a). Samples from the drainage pipe have $\chi_{\mathrm{LF}}$ values of $4.16-4.83 \times 10^{-6} \mathrm{~m}^{3} /$ $\mathrm{kg}$, while samples from the storage pond have $\chi_{\mathrm{LF}}$ values of $4.61 \times 10^{-6}-5.44 \times 10^{-5} \mathrm{~m}^{3} / \mathrm{kg}$, suggesting the drainage pipe samples were hydrodynamically modified (Fig. $4 \mathrm{a}$ inset). Simple least squares linear regression of $\chi_{\mathrm{LF}}$ versus total $\%$ ash in the river samples yields a good correlation $\left(R^{2}=0.83\right)$ (Fig. 4a). Thirty-two samples with total ash concentrations between 0 and $12 \%$ form a dense cloud (Group A) on the $\chi_{\mathrm{LF}}$ versus total \% ash plot. The upper limit of Group $A$ is bounded by a maximum $\chi_{\mathrm{LF}}<8 \times 10^{-7} \mathrm{~m}^{3} / \mathrm{kg}$. The coefficient of determination, $R^{2}$, for samples only in Group A versus $\chi_{\mathrm{LF}}$ is 0.16 (not significant). In contrast, sixteen samples with total 


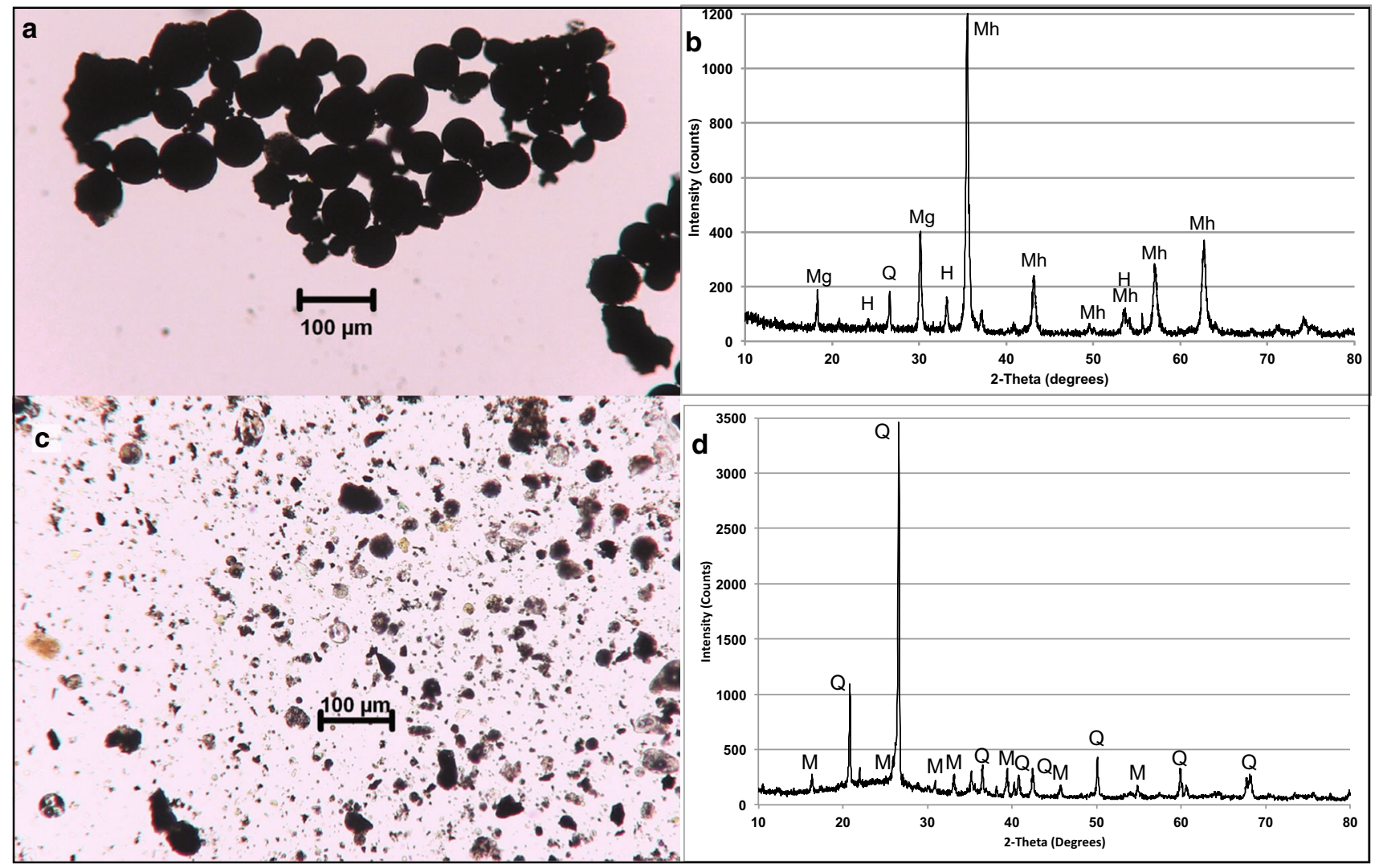

Fig. 2 a Photomicrograph of ash particles in the magnetic fraction. b XRD pattern of MF. c Ash particles in the non-magnetic fraction. $\mathbf{d}$ XRD pattern of NMF of a sample (AP-1) from the CCR storage pond. $M g$ magnetite, $M h$ maghemite, $H$ hematite, $M$ mullite, $Q$ quartz

ash $\geq 12 \%$ all have $\chi_{\mathrm{LF}}$ between $8 \times 10^{-7}$ and $6 \times 10^{-6}$ $\mathrm{m}^{3} / \mathrm{kg}$. The $R^{2}$, for samples only in Group B versus $\chi_{\mathrm{LF}}$ is $0.58(p \leq 0.001)$.

Amorphous ash, black and orange ash spheres are each strongly correlated with $\chi_{\mathrm{LF}}$ with $R^{2}$ values of $0.88,0.73$ and 0.68 respectively (Fig. 4b). Clear spheres are also correlated $\left(R^{2}=0.59\right)$. As expected ash rods, which are composed of carbon are not correlated with $\chi_{\mathrm{LF}}$ $\left(R^{2}=0.06\right)$ (Fig. 4b).

Thermomagnetic curves confirm that magnetite and slightly oxidized magnetite (maghemite) are the carriers of magnetic susceptibility (Fig. 5a). We also explored the use of anhysteretic remanent magnetization (ARM) and hysteresis parameters as tracers of ash particles in river sediment. Simple least squares linear regression of ARM versus total \% ash yields a strong correlation $\left(R^{2}=0.79\right)$ (Fig. 5b). The ratio of ARM to $\chi_{\mathrm{LF}}$ is relatively constant (Fig. 5c), suggesting $\chi_{\mathrm{LF}}$ and ARM are both tracking the concentration of magnetic spherules in coal ash.

Hysteresis parameters delineate native sediment, ash-bearing sediment, and diabase dikes. The influence of hematite is observed in river sediment with low ash content. Hematite elevates $H_{\mathrm{CR}} / H_{\mathrm{C}}$ values and places these samples on the righthand section of the pseudo-single domain (PSD) field of the
Day Plot (Fig. 5d). Samples with ash content above 13-14\% form a cluster on the lower left-hand margin of the PSD field. $M_{\mathrm{R}} / M_{\mathrm{S}}$ values for ash-bearing Dan River sediment range from 0.07 to 0.18 , with an average of $0.14 . H_{\mathrm{CR}} / H_{\mathrm{C}}$ values for sediment with $>13-14 \%$ ash range from 1.13 to 2.61 with an average of 1.81 . These are similar to the hysteresis parameters observed for Kingston Fossil Plant coal ash (Cowan et al. 2015). In contrast, diabase dikes have $M_{\mathrm{R}} / M_{\mathrm{S}}$ values between 0.22 and 0.45 (McEnroe and Brown 2000), allowing a means to identify samples for which sediment derived from dikes could interfere with the use of $\chi_{\mathrm{LF}}$ in coal ash detection.

\section{Statistical analysis}

A scatter plot of $\chi_{\mathrm{LF}}$ as a function of principal component axis one (PCA-1) (Fig. 6a, axis loadings in Table 1) illustrates the inverse correlation between ash abundance (right) versus quartz grain abundance (left). When sample Groups A and B, defined by total ash (\%) greater or less than $12 \%$ in Fig. 4 a are overlain on Fig. 6a samples fall in the same groups, with the exception of two outliers (AP 51515-2 and MR 51415-2).

A scatter plot of samples on PCA-2 versus PCA-1 (Fig. 6b) also highlights Groups $\mathrm{A}$ and $\mathrm{B}$. This 


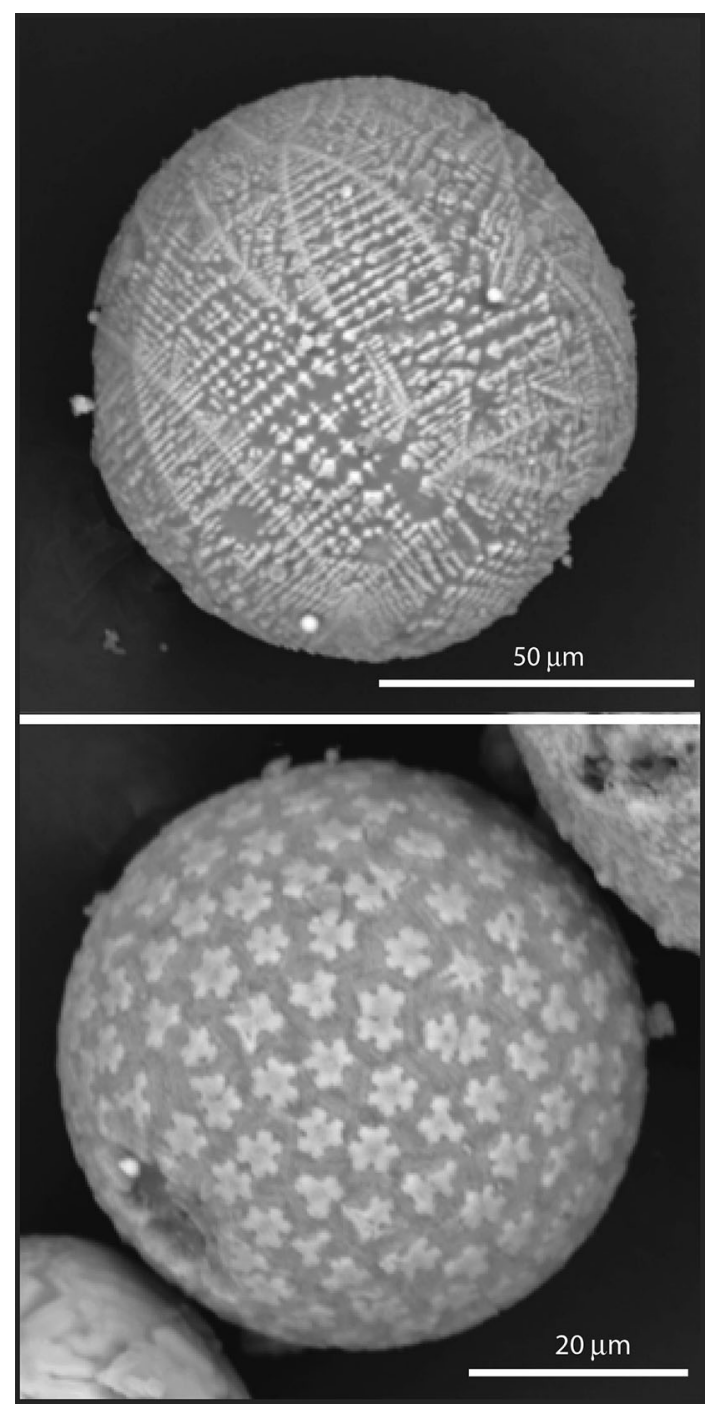

Fig. 3 Examples of magnetospheres in the MF from the CCR pond. SEM backscatter shows bright maghemite/magnetite crystals forming delicate repeating patterns on dark aluminosilicate spheres

demonstrates that these groups can be defined by both total ash abundance (Fig. 4a) and by the individual contributions of each ash and mineral type as in Fig. 6b. Within the two primary groups (A and B) of Fig. 7b, samples with greater ash content plot to the right (solid symbols) and those with less ash plot to the left (open symbols). The distribution of samples on PCA-2 reflects an inverse relationship in Group A between the abundance of clay and mica (top) and quartz grains (bottom) (see loading coefficients in Table 1).

A pairwise comparison of the relative abundance of sample components (Fig. 7) can be summarized in six fields (Supplemental Table S3). Ash types are strongly positively correlated with each other and strongly negatively correlated with mineral grain types. Fine sediment (clays and organic matter) and mica (Fine/Light) are very strongly correlated (positive) with each other and
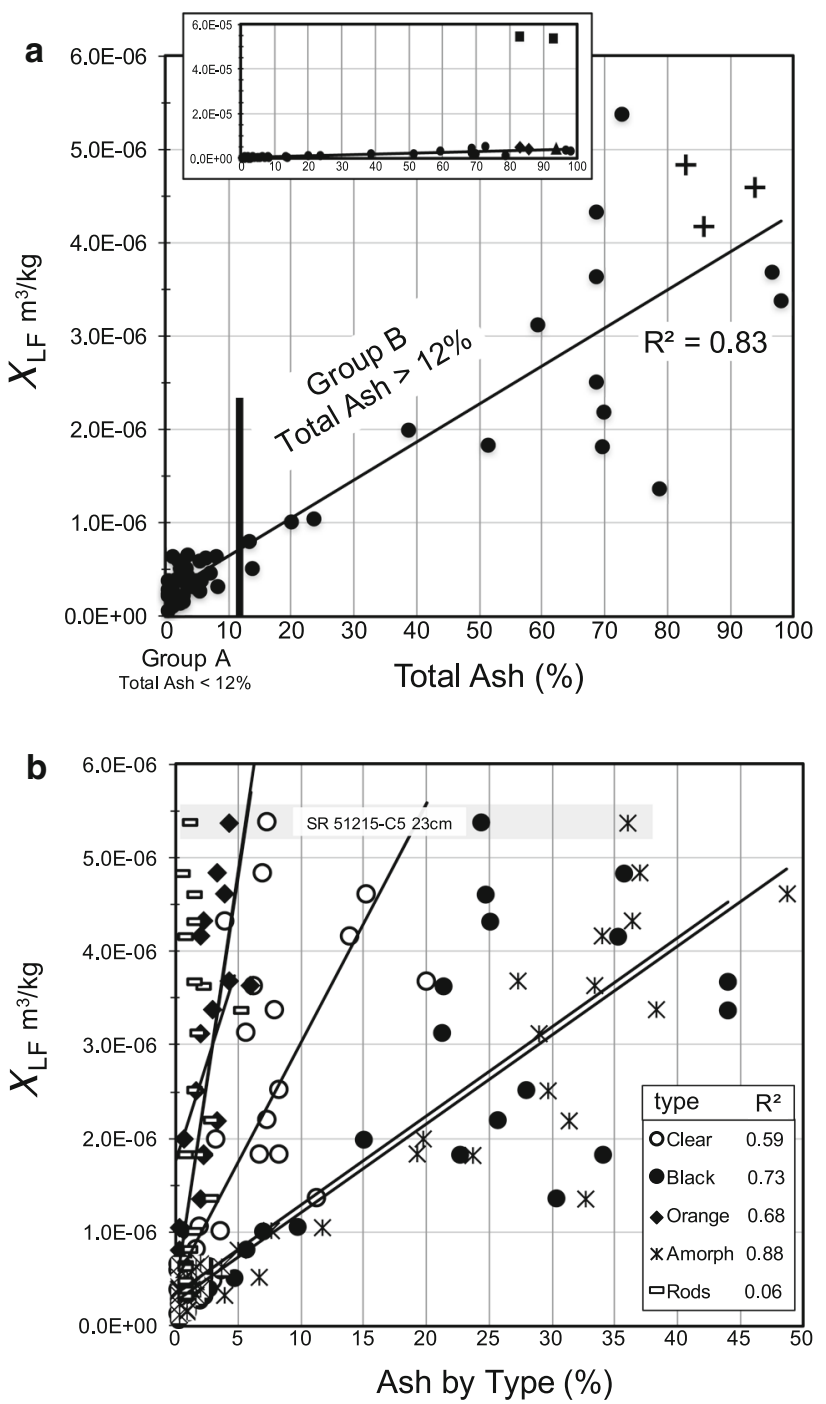

Fig. 4 a $\chi_{\mathrm{LF}}$ as a function of total ash (\%) for each sample. Two groups are distinguished based on total ash: $\mathrm{A}<12 \%$ with low $\chi_{\mathrm{LF}}$ and $\mathrm{B} \geq 12 \%$, generally higher $\chi_{\mathrm{LF}}$. Circles are river samples, crosses from pond drainpipe and pond. Simple least squares linear regression $\left(R^{2}\right)$ is related for all samples. Inset is a plot of the same data, with the addition of two pond samples (squares) and axes scaled to accommodate. $\mathbf{b} \chi_{\mathrm{LF}}$ as a function of ash type (\%). Simple least squares linear regression $\left(R^{2}\right)$ is related for each ash type. For each sample, symbols align horizontally (same $\chi_{\text {LF }}$ ), e.g., SR 51215-C5 $23 \mathrm{~cm}$. Symbols are omitted for ash types of zero value, resulting in fewer symbols for some samples

moderately strongly correlated (negative) with ash types. Other relationships vary in their level of significance and direction.

\section{Distribution of ash deposits}

Samples collected during October 2014 from 0 to $3 \mathrm{~km}$ downstream of the spill ranged from 2.7 to $72.7 \%$ ash (Table 1). The highest ash content was observed in layers buried within the banks above the water level. The ash 


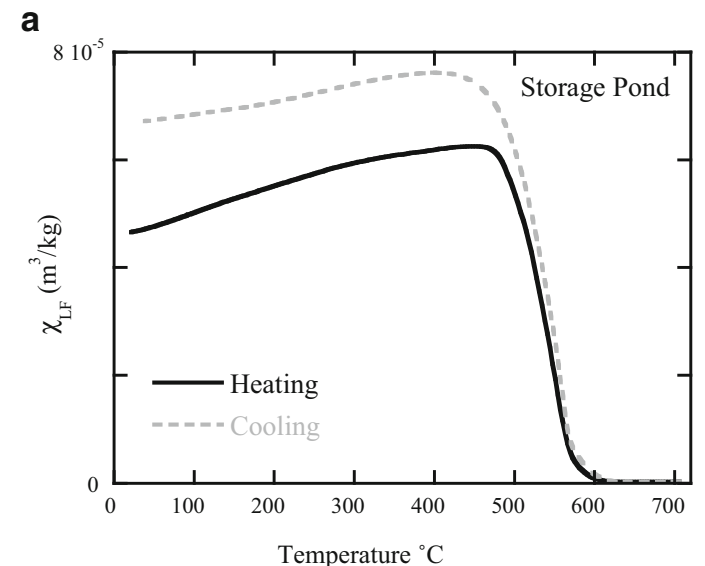

C

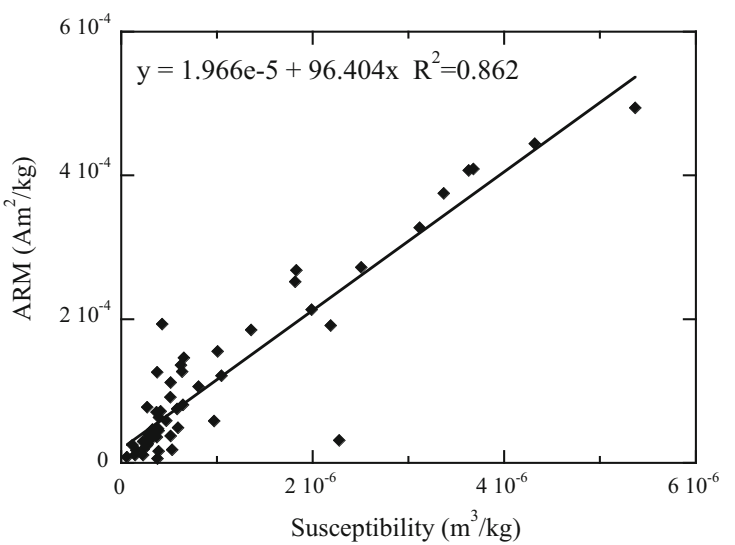

Fig. 5 a Thermomagnetic curves from the storage pond sample measured in argon exhibit a rapid decay of $\chi_{\mathrm{LF}}$ between 460 and $600{ }^{\circ} \mathrm{C}$. b Anhysteretic remanent magnetization (ARM) versus total

content of samples collected from the riverbed was low. Samples with ash were dominated by black spheres and amorphous ash but also included minerals contributed by the watershed especially mica and quartz (Table 1). During the May 2015 trip, samples were collected with high (up to 99\%) ash content near the Schoolfield Reservoir, some $32 \mathrm{~km}$ downstream of the Steam Plant. At the sampling locations downstream of the reservoir only a few percent ash were measured in any sample (Table 1).

The highest ash content in May was identified within discrete layers from cores collected from two quiet water settings upstream of Schoolfield Reservoir. Cores C5/C5b at Station 5 were collected from the inside of a meander bend (Fig. 1b). Two discrete ash layers are preserved, a layer from $42-45 \mathrm{~cm}$ depth containing $98 \%$ ash (Fig. 8). This layer is capped by $20 \mathrm{~cm}$ of fine to medium sand. At $22 \mathrm{~cm}$ depth a second ash layer occurred with $97 \%$ ash. Cores $\mathrm{C} 2 / \mathrm{C} 3$ were collected at Station 4 near the confluence with a small tributary stream and show a similar depositional pattern. A $3 \mathrm{~cm}$ layer with $95 \%$ ash occurs from $54-51 \mathrm{~cm}$ depth followed by $39 \mathrm{~cm}$ of mud with an ash content ranging from 0 to

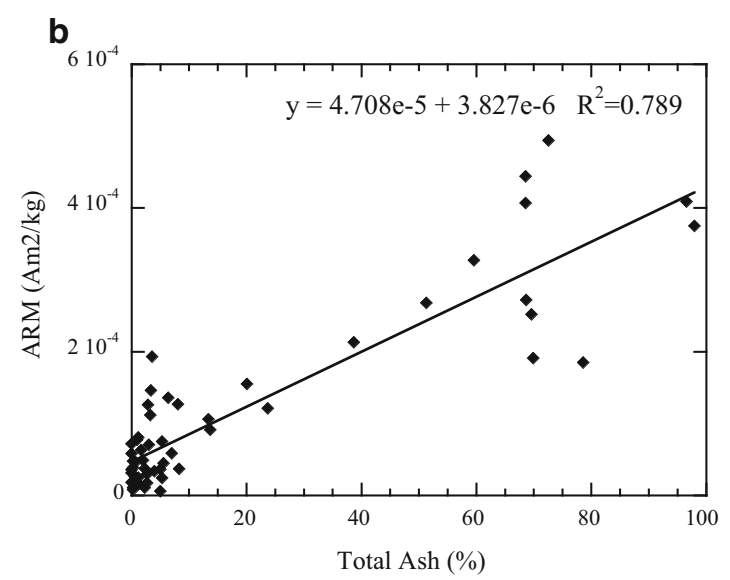

d

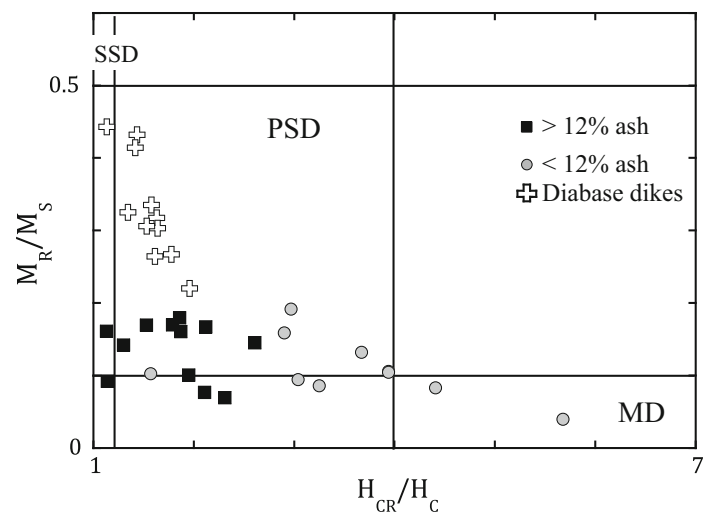

$\%$ ash in river samples determined by point counting. c ARM versus $\chi_{\mathrm{LF}}$ for river samples. d Day plot of river samples (this study) and diabase dikes

$9 \%$. A $2 \mathrm{~cm}$ layer containing $70 \%$ ash is buried by $10 \mathrm{~cm}$ of sediment with low ash content (Fig. 8).

Ash comprising the deeper layers is morphologically similar in in both cores but differs from the upper layers. Deeper ash layers have high percent ash with small particle diameter and lacy amorphous particles and rods and few minerals (Table 1). At both sites the ash layers are separated by sediment containing little or no ash (Fig. 8).

\section{Discussion}

\section{Single source of ash with high MF}

Ash slurry flowed into the Dan River as the primary settling pond at the Duke Energy Steam Plant completely drained over a 6-day period (Messinger and Silman 2016). Samples from this CCR pond are characteristic of fly ash and include a small number of mineral grains either blown or washed into the open pond (Table 2). Up to $17 \mathrm{wt} \%$ is in the MF, which is on 

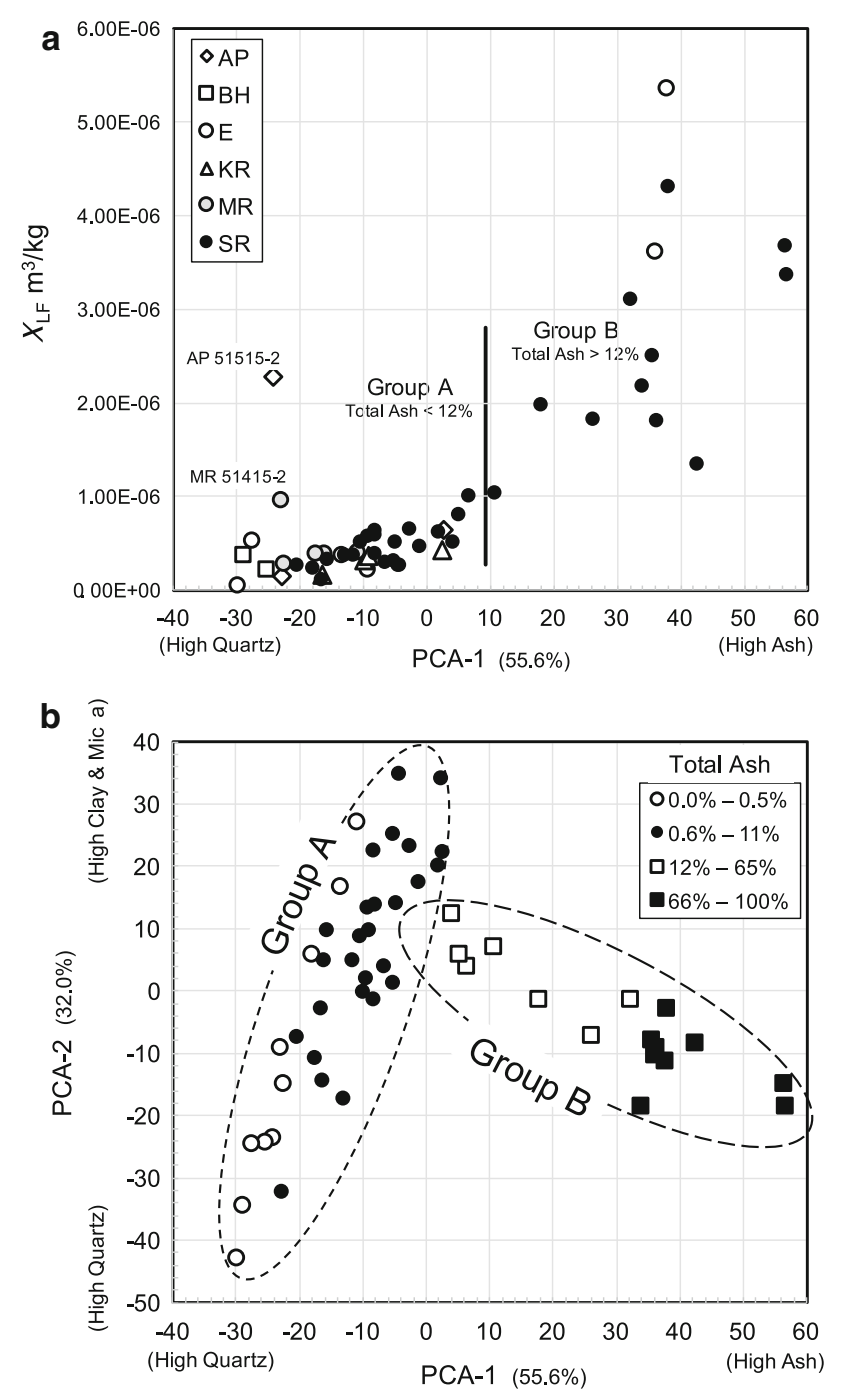

Fig. 6 a $\chi_{L F}$ as a function of PCA1 (arcsine transformation of compositional abundance, Table 1). Groups A and B as defined by total ash abundance in Fig. 4a two outliers are labeled. b Scatter plot of principal component values (same samples as in part a), plotted on PCA-2 versus PCA-1 (87.6\% of total variance). Ellipses are drawn to highlight groups defined by total ash abundance (Fig. 4a) and do not represent confidence limits. Open symbols are samples (subgroups) with lower total ash within the two primary groups and solid symbols are samples (subgroups) with higher total ash in the two primary groups

the high side of values reported for CCRs in the literature (Veneva et al. 2004; Lu et al. 2009) and significantly aids in ash detection using $\chi_{\mathrm{LF}}$.

Results from the correlation of ash components (Fig. 7, Supplemental Table S3) and principal component analysis based on their relative abundance (Fig. 6) suggest that the ash components in all samples collected from the riverbed have the same origin and similar transport history. For example, PCA-2 versus PCA-1 shows a narrow, gradational field of compositions rather than discrete clusters of points (Fig. 6b). This coal ash spill differs from the TVA spill because ash entered the Dan River as a mixed ashwater slurry through a drainpipe rather than as a flow of semi-dry solids into the river. In the TVA case, the Emory River was able to erode fresh ash buried within the riverbed years after the spill thus introducing new populations of ash types. In addition, other anthropogenic magnetic particles were transported into the watershed from the heavily industrialized Tennessee River watershed (Cowan et al. 2015). The Duke Energy spill appears to present a simpler case as far as magnetic characteristics of ash are concerned.

\section{Ash $\chi_{\text {LF }}$ versus background geology}

All of the samples with a large component of ash were collected upstream of the Schoolfield Dam in Danville. Therefore the effects of native sediment derived from the igneous/metamorphic rocks including diabase, granitic gneiss, and metavolcanics as well as the sedimentary rocks in the Danville Triassic Basin can be considered (Fig. 1b). Measurements show that background $\chi_{\mathrm{LF}}$ of native sediment rarely interfered with the detection of the magnetic signal of coal ash (Fig. 6), as $\chi_{\mathrm{LF}}$ values for the ash storage pond are 2-3 orders of magnitude higher than those of the ash-free sediment.

Two samples, however, 51415-2 collected from MR and 51515-2 collected from AP had high $\chi_{\mathrm{LF}}$ although they contain no coal ash (Table 1, Fig. 6a). Both of these samples originated from a section of the river crossing metavolcanics and PLM indicates higher percent quartz grains in these samples. However, unlike samples with low $\chi_{\mathrm{LF}}$, these quartz grains had an opaque black coating on their outer surface. Surface bound Fe oxides on quartz grains have been attributed to soil forming processes in other $\chi_{\mathrm{LF}}$ watershed studies (Caitcheon 1998). Although the presence of $\mathrm{Fe}$ oxides on quartz grains could complicate the detection of ash in riverbed samples, the coal ash in the Dan River was usually deposited with fine-grained sediment rather than within sand beds.

Diabase dikes, which have $\chi_{\mathrm{LF}}$ values comparable to the coal ash samples, have the potential to complicate ash detection if this material is present in large quantities. Our ash-free river samples, which represent a mixture of both Triassic sedimentary rocks and diabase dikes, suggest no more that $5 \mathrm{wt} \%$ of the sediment comes from the dikes, resulting in a maximum $\chi_{\mathrm{LF}}$ value of $1-5 \times 10^{-7} \mathrm{~m}^{3} / \mathrm{kg}$. This is easily distinguished from the threshold of $8 \times 10^{-7} \mathrm{~m}^{3} / \mathrm{kg}$ for an ash content of $\geq 12 \%$. In addition, hysteresis measurements provide a secondary check on diabase dike content via a $M_{\mathrm{R}} / M_{\mathrm{S}}$ value above 0.22 (Fig. 5d). 
Pearson Correlation Coefficient ( $r$ ) and Significance level

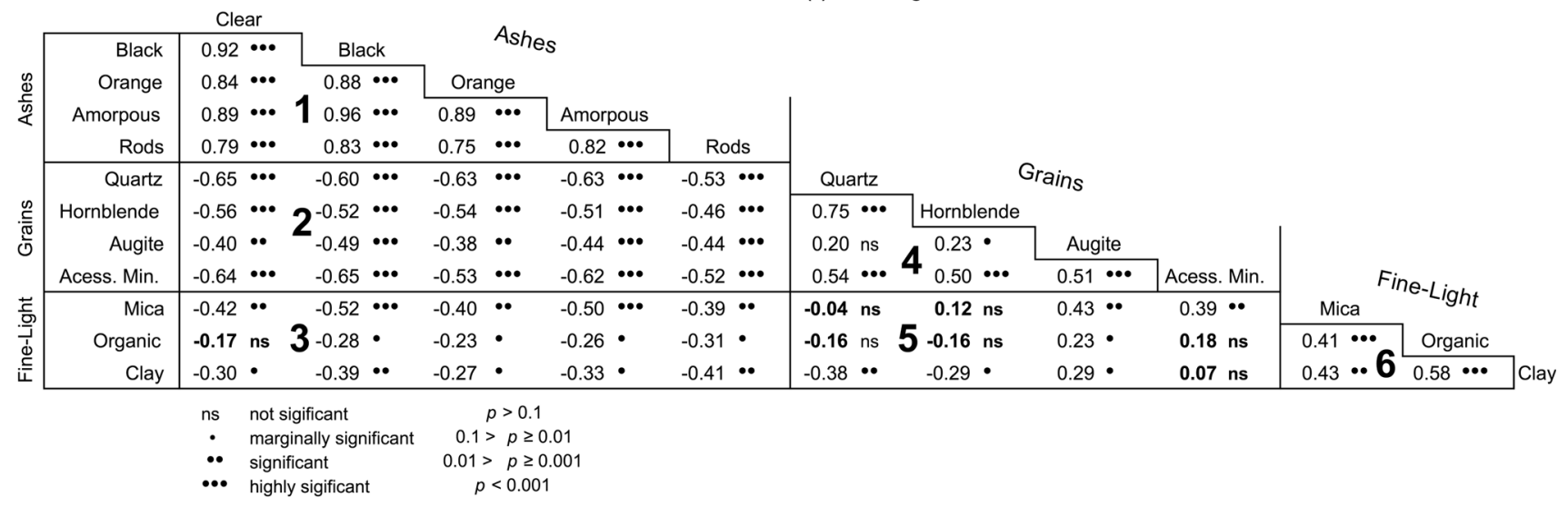

Fig. 7 Correlations matrix (Pearson $r$ ) for arcsine transformed compositional abundance data, Table 1. Significance levels for correlation coefficients for each pairwise comparison are shown by symbols. Six types of data are labeled: 1. Ash types, 2. Ash versus

\section{Transport and burial of ash in the Dan River after the spill}

Ash was recovered from riverbed sediments in the upper reaches of the Dan River in May 2015, 15 months after the spill. The ash distribution is discontinuous and occurs in areas outside of the main river flow. All ash types are strongly positively correlated with each other suggesting that ash particles were generally transported downstream together from a single source (Fig. 7, Supplemental Table S3). This is expected since fly ash is predominately in the silt size fraction (Cowan et al. 2013) and is transported in suspension. A strong inverse correlation in ash type versus mineral grains results from the mixing of two discrete populations, native suspended sediment and coal ash pollution. Mineral grains, like quartz, are not significantly correlated with low-density mica and organic matter (Fig. 7), which results from deposition under different energy conditions in the river. Ash types are negatively correlated with mica and clay minerals but not organic matter (Fig. 7). This reflects deposition in lower energy settings of the Dan River along with input of low-density organic matter.

The highest ash concentrations were sampled just upstream of Schoolfield Reservoir and are associated with the inside of meander bends, the confluence of a tributary stream, and on the lee side of an island upstream of the reservoir (Fig. 1b). Concentrations of ash were relatively low within samples collected near the dam at Schoolfield Reservoir because the city of Danville opened the sluice gates allowing deposited ash to flush downstream prior to dredging by Duke Energy in May-June 2014.

Beds of pure ash were identified within two push cores that penetrated the riverbed upstream of the reservoir (at mineral grains, 3. Ash versus suspended sediment, 4. Mineral grains versus mineral grains, 5 . Mineral grains versus suspended sediment, and 6. Suspended sediment

Stations 4 and 5 in Fig. 1b). The occurrence of the layers in each core collected from slack water areas on opposite sides of the river suggests that the initial spill was sampled as well as a second layer with high $\%$ ash (Fig. 8). The morphology of ash within the deeper layer is similar to the composition within the CCR pond (Table 2) including the presence of carbonaceous lacy particles and rods (Supplemental Fig. S1). The $\chi_{\mathrm{LF}}$ is slightly lower in the deeper layer because of the diamagnetic properties of the carbonaceous ash particles (Fig. 8). These fragile particles were rapidly deposited soon after the spill and did not remain at the surface or within the river long enough to break up. At Station 5 (core C5/C5b) located on the inside of the meander bend, $20 \mathrm{~cm}$ of fine to medium sand containing low $\%$ ash buried this layer. The ash layer deposited immediately above this sand contains $98 \%$ ash but with a larger number of spheres and fewer rods and lacy particles, suggesting that it was eroded from the banks upstream, resuspended and transported downstream. Ash was observed to coat the stream banks immediately after the spill and high discharge could have mobilized it depositing the upper layer of ash. A similar depositional pattern occurs at Station 4 (core C2/C3) collected further downstream on the opposite bank, although the upper layer is diluted with native sediment (Fig. 8).

A chronology has not been developed for the cores so it cannot be exactly determined when the upper ash beds were deposited. However, high discharge events that occurred after the spill are recorded on a hydrograph from the U.S.G.S. Station 02075045 at AP (Fig. 1, Supplemental Fig. S3). Such events increased the river stage and mobilized ash further downstream. The spill occurred during a low flow period in February 2014 when the deepest layer in both cores was deposited. In April, two flood events 


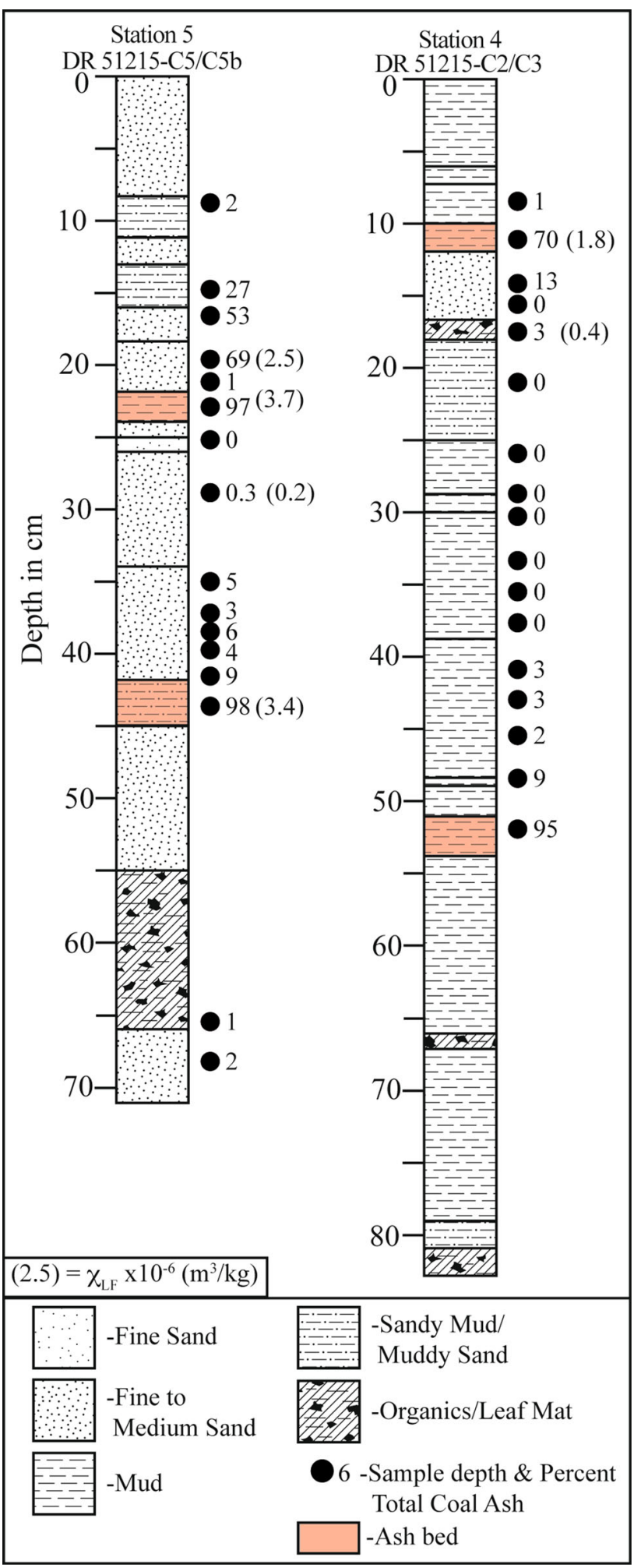

Fig. 8 Core logs and percent total ash determined by point counting at Station 5 (Core C5/C5b) and Station 4 (Core C2/C3). The station locations are shown on Fig. 1b occurred when the mean daily discharge reached $13,500 \mathrm{cfs}$ (Supplemental Fig. S3). A second flood event of 17,900 cfs occurred one year later on April 21, 2015 (Supplemental Fig. S3). Attributing the upper ash layer to deposition from the spring floods in April 2014 is logical because this is the first large discharge event post-spill and the fragile lacy ash and rods that were deposited in the deepest layer are absent. This observation highlights the episodic deposition of sediment in piedmont streams, where $20 \mathrm{~cm}$ of fine to medium sand is deposited on the inside of a meander bend in a little over 1 month. A small amount of ash was incorporated into the sand although it is diminished up core (Fig. 8). At Station 4, a similar pattern occurs although almost twice the thickness of sediment was deposited between the two ash layers. This fine-grained sediment is likely supplied by a tributary stream entering near the core site. This observation explains why ash was not recovered in all of the samples that we collected in May 2015. In high-energy reaches, ash had already been scoured from the riverbed and buried in slack water areas downstream. In some quiet water areas such as in the Kerr Reservoir small quantities of ash were detected within grab samples and short cores (Table 1) but ash from the February 2014 spill was buried too deeply for us to penetrate with our samplers. However, in quiet water areas upstream of Schoolfield Reservoir pure ash remains buried in the riverbed where it is accessible to benthic organisms or can be eroded and transported downstream during future high flows.

\section{Conclusions}

$\chi_{\mathrm{LF}}$ Measurements can be used for tracking coal ash released into the Dan River from the Duke Energy coal ash spill, even though the watershed geology is magnetically complex, including diabase dikes and granitic gneiss. Coal ash from the failed storage pond is a heterogeneous, finegrained material containing up to $17 \mathrm{wt} \% \mathrm{MF}$, composed of maghemite and magnetite. Point counting under optical polarizing microscope shows heterogeneous ash including clear, black, and orange spheres, amorphous black particles and ash rods. Lacy opaque particles and ash rods are distinctive but in low abundance. They are composed of carbon and occur in samples from the storage pond and riverbed samples deposited by the initial spill.

Ash was recovered in riverbed sediment between the spill site and 20 miles downstream near Schoolfield Reservoir. Ash distribution was discontinuous, favoring quiet water areas such as the inside of meander bends, the 
confluence of a tributary stream, and on the lee side of islands. All ash types are strongly inversely correlated with mineral grains in the riverbed indicating one source of coal ash. $\chi_{\mathrm{LF}}$ values $>8 \times 10^{-7} \mathrm{~m}^{3} / \mathrm{kg}$ indicate sediment containing at least $12 \%$ ash content. Anhysteretic remanent magnetization and hysteresis parameters delineate native sediment, ash-bearing sediment, and diabase dikes. Diabase dikes contributed a small amount of the magnetic signal with $M_{\mathrm{R}} / M_{\mathrm{S}}$ values above 0.22

Cores document the occurrence of $4 \mathrm{~cm}$-thick beds of pure ash buried by river sediment in two locations upstream of Schoolfield Reservoir. A layer of similar thickness but lacking fragile ash rods was deposited stratigraphically above the initial spill deposits and suggests transport by a subsequent high discharge event. The rapid burial of ash within the riverbed in low energy areas indicates the episodic nature of sediment transport in highenergy piedmont streams. These ash beds, along with their associated heavy metals are accessible to benthic organisms or can be eroded and transported downstream during high flows.

Acknowledgements Funding for this project was provided by Appalachian State University Research Council and the Office of Student Research. We wish to thank Brian Williams, Dan River Basin Association for help with local knowledge and field logistics, Madeline Schreiber for providing samples from the CCR pond, Dennis Kent for providing bedrock samples from Eden, NC, and David Sharpe for assistance with magnetic susceptibility and ARM measurements. Analytical support was provided in the Department of Geology at ASU by Anthony Love and Dr. Richard Abbott. Grant Harvey and Chelsea Vaughn helped with sample collection on the river

\section{References}

Alexander CC, Thorpe AN, Senftle FE (1979) Basic magnetic properties of bituminous coal. Fuel 58:857-863

Blaha U, Sapkota B, Appel E, Stanjek H, Rösler W (2008) Microscale grain-size analysis and magnetic properties of coal-fired power plant fly ash and its relevance for environmental magnetic pollution studies. Atmos Environ 42:8359-8370

Caitcheon GG (1998) The significance of various sediment magnetic mineral fractions for tracing sediment sources in Killimicat Creek. CATENA 32:131-142

Carriker NE, Jones DS, Wall SJ, Stojak AR (2015) Ecological risk assessment for residual coal fly ash at Watts Bar Reservoir, Tennessee. Integr Environ Assess Manag 11:80-87

Cowan EA, Seramur KC, Hageman SJ (2013) Magnetic susceptibility measurements to detect coal fly ash from the Kingston Tennessee spill in Watts Bar Reservoir. Environ Pollut 174:179-188

Cowan EA, Gaspari DP, Brachfeld SA, Seramur KC (2015) Characterization of coal ash released in the TVA Kingston spill to facilitate detection of ash in river systems using magnetic methods. Fuel 159:208-314

DeBoer J, Snider FG (1979) Magnetic and chemical variations of Mesozoic diabase dikes from eastern North America: evidence for a hotspot in the Carolinas? Geol Soc Am Bull 90:185-198
Fisher GL, Chang DPY, Brummer M (1976) Fly ash collected from electrostatic precipitators: microcrystalline structures and the mystery of the spheres. Science 192:553-555

Fisher GL, Prentice BA, Silberman D, Ondov JM, Blermann AH, Ragaini RC, McFarland AR (1978) Physical and morphological studies of size-classified coal fly ash. Environ Sci Technol $12: 447-451$

Flanders PJ (1994) Collection, measurement, and analysis of airborne magnetic particulates from pollution in the environment. J Appl Phys 75:5931-5936

Hower JC (2012) Petrographic examination of coal-combustion fly ash. Int J Coal Geol 92:90-97

Jordanova D, Jordanova N, Hoffmann V (2006) Magnetic mineralogy and grain-size dependence of hysteresis parameters of single spherules from industrial waste products. Phys Earth Planet Inter 154:255-265

Kent DV, Olsen PE (1997) Paleomagnetism of Upper Triassic continental sedimentary rocks from the Dan River-Danville rift basin (eastern North America). Geol Soc Am Bull 109:366-377

Kodama KP, Mowery A (1994) Paleomagnetism of the Sassamansville diabase, Newark Basin, southeastern Pennsylvania: support for Middle Jurassic high-latitude paleopoles for North America. Geol Soc Am Bull 106:952-961

Lemly AD (2015) Damage cost of the Dan River coal ash spill. Environ Pollut 197:55-61

Lemly AD, Skorupa JP (2012) Wildlife and coal waste policy debate: proposed rules for coal waste disposal ignore lessons from 45 years of wildlife poisoning. Environ Sci Technol 46:8595-8600

Lu SG, Chen YY, Shan HD, Bai SQ (2009) Mineralogy and heavy metal leachability of magnetic fractions separated from some Chinese coal fly ashes. J Hazard Mater 169:246-255

Magiera T, Jabłońska M, Strzyszcz Z, Rachwal M (2011) Morphological and mineralogical forms of technogenic magnetic particles in industrial dusts. Atmos Environ 45:4281-4290

McEnroe SA, Brown LL (2000) Paleomagnetism, rock magnetism, and geochemistry of Jurassic dykes and correlative redbeds, Massachusetts, USA. Geophys J Int 143:22-28

Messinger M, Silman M (2016) Unmanned aerial vehicles for the assessment and monitoring of environmental contamination: an example from coal ash spills. Environ Pollut 218:889-894

Olsen PE, Reid JC, Taylor KB, Whiteside JH, Kent DV (2015) Revised stratigraphy of Late Triassic Age Strata of the Dan River Basin (Virginia and North Carolina, USA) based on drill core and outcrop data. South Geol 51:1-31

Otter RR, Bailey FC, Fortner AM, Adams SM (2012) Trophic status and metal bioaccumulation differences in multiple fish species exposed to coal ash-associated metals. Ecotoxicol Environ Saf 85:30-36

Presuel-Moreno FJ, Sagüés AA (2009) Bulk magnetic susceptibility measurements for determination of fly ash presence in concrete. Cem Concr Res 39:95-101

Rader EK, Evans NH (1993) Geologic map of Virginia; expanded explanation. Virginia Division of Mineral Resources, 1:500,000scale

Reid JC, Milici RC (2008) Hydrocarbon source rocks in the Deep River and Dan River Triassic Basin, North Carolina. U.S. Geological survey open-file report 2008-1108: 28 p

Reusser L, Bierman P, Rood D (2015) Quantifying human impacts on rates of erosion and sediment transport at a landscape scale. Geol 43:171-174

Rhodes TS, Conrad SG (1985) Geologic map of North Carolina. Department of Natural Resources and Community Development, Division of Land Resources, and the NC Geological Survey, 1:500,000-scale

Schlanger Z (2014) With $92 \%$ of coal ash still coating North Carolina River Bed, Duke Energy declares cleanup complete, Newsweek 
(July 21, 2014). http://www.newsweek.com/92-coal-ash-still-coat ing-north-carolina-river-duke-energy-declares-cleanup-260084

Scott S, Zeller C (2011) 2D Sediment transport simulation to support the monitored natural recovery process for Watts Bar Reservoir. Abstracts: TVA-Kingston fly ash release environmental research symposium, 2-3, 2011 August, p. 15

Smith WA (1987) Paleomagnetic results from a crosscutting systems of northwest and north-south trending diabase dikes in the North Carolina Piedmont. Tectonophys 136:137-150

TVA (Tennessee Valley Authority) (2013) Kingston ash recovery project non-time-critical removal action for the river system long-term monitoring sampling and analysis plan (SAP), EPAAO-059 [cited May 16, 2013]. https://www.tva.gov/file_source/ TVA/Site\%20Content/About\%20TVA/Guidelines\%20and\%20 Reports/Kingston\%20Recover\%20Project/SAP.pdf

USEPA (United States Environmental Protection Agency) (2014) EPA response to release of coal ash into the Dan River. http:// epa.gov//region4duke-energy/index.html
USFWS (United States Fish and Wildlife Service) (2014) U.S. Fish and wildlife service continuing to help in Dan River coal ash spill. News Release-Southeast Region. http://www.fws.gov/ southeast/news/2014/012.html/

VDEQ (Virginia Department of Environmental Quality) (2014) Dan River coal ash spill. http://www.deq.virginia.gov/Connectwith DEQ/EnvironmentalInformation/DanRiverCoalAshSpill.aspx. Accessed 1 Oct 2017

Veneva L, Hoffman V, Jordanova D, Jordanova N, Fehr Th (2004) Rock magnetic, mineralogical and microstructural characterization of fly ashes from Bulgarian power plants and the nearby anthropogenic soils. Phys Chem Earth 29:1011-1023

Walls SJ, Jones DS, Stojak AR, Carriker NE (2015) Ecological risk assessment for residual coal fly ash at Watts Bar Reservoir, Tennessee: site setting and problem formulation. Integr Environ Assess Manag 11:32-42

Wang XS (2014) Mineralogical and chemical composition of magnetic fly ash fraction. Environ Earth Sci 71:1673-1681 